\title{
JUBILEUSZ PROFESORA SIERGIEJA NIEKLUDOWA
}

31 marca 2016 roku 75. urodziny obchodził Profesor Siergiej Niekludow, światowej sławy rosyjski folklorysta, założyciel i wieloletni dyrektor Centrum Typologii i Semiotyki Folkloru Rosyjskiego Państwowego Uniwersytetu Humanistycznego w Moskwie, kierownik Pracowni Folklorystyki Praktycznej przy Szkole Aktualnych Badań Humanistycznych (ШАГИ ИОН РАНХиГС). Jubilat jest redaktorem naukowym znanej serii „Tradycja - tekst - folklor: typologia i semiotyka” („Традиция текст - фольклор: типология и семиотика"), redaktorem naczelnym czasopisma «ШАГИ / STЕРS», członkiem kolegium redakcyjnego, a wcześniej naczelnym redaktorem prestiżowego czasopisma folklorystycznego „Живая старина” oraz „Zeszytów Naukowych RGGU” („Вестник РГГУ. Сер. История. Филология. Культурология. Востоковедение"), członkiem Międzynarodowego Związku Folklorystów (Folklore Fellows an International Network of Folklorist), laureatem międzynarodowej nagrody im. G. Pitre i S. Marino za najlepszą pracę z zakresu folklorystyki (Premio Internazionale di Studi Etnoantropologici Pitré-Salomone Marino,1972).

Profesor Siergiej Niekludow urodził się 31 marca 1941 roku w Moskwie. Jest absolwentem Moskiewskiego Uniwersytetu Państwowego, na którym w 1965 roku obronił pracę magisterską, napisaną pod kierunkiem samego Eleazara Meletyńskiego. Stopień doktora nauk humanistycznych Jubilat otrzymał w roku 1973, natomiast doktora habilitowanego w roku 1985. Problematyka dysertacji dotyczy odpowiednio tradycji epickiej narodów Azji Centralnej i jej związków z europejskim Średniowieczem oraz genezy i ewolucji tradycji epickich w mongolskiej literaturze klasycznej.

Od 1966 roku Profesor Niekludow brał czynny udział w kolejnych edycjach Szkoły Letniej organizowanej przez Jurija Łotmana w Tartu, uczestniczył w międzynarodowych konferencjach naukowych w Rosji, w Niemczech, Włoszech, Francji, Holandii, Brazylii, Chinach, Mongolii i Estonii, prowadził wykłady z teorii folkloru oraz współczesnych jego form na uniwersytetach Kanady i Brazylii, a także wielu uczelniach europejskich, w tym m.in. na Uniwersytecie Mikołaja Kopernika w Toruniu (2014), systematycznie prowadził badania terenowe w Mongolii i Buriacji (1974, 1976, 1978, 2006-2011).

Aktualnie bibliografia Jego prac liczy 589 różnego rodzaju pozycji. Są wśród nich m.in. autorskie monografie naukowe, prace powstałe we współautorstwie, redakcje monografii i prac zbiorowych, artykuły, publikacje tez, materiałów pokonferencyjnych oraz seminariów, recenzje, 42 hasła do encyklopedii Mity narodów świata (Mupbl народов мира), liczne tłumaczenia prac Jubilata na języki obce (niemiecki, chiński, włoski, hiszpański, portugalski, angielski, francuski, polski, węgierski, łotewski, bułgarski), wystąpienia w radio i telewizji, wywiady, notki prasowe, wykłady interaktywne.

Zainteresowania naukowe Profesora Niekludowa są bardzo szerokie i koncentrują się wokół teorii folkloru, współczesnych jego form, mitologii i eposu narodów Mongolii. W wywiadzie dla czasopisma „Живая старина” (1/2016) Badacz mówi, że lubi pisać teksty, które są częścią jakiegoś większego projektu. Tak było w przypadku jego pierwszego obiektu naukowej refleksji związanego z czasem i przestrzenią w bylinie, czemu poświęcił swój pierwszy artykuł naukowy, a następnie kontynuował temat przez całe swoje życie. Zwieńczeniem tych zainteresowań jest wydana ostatnio monografia, która powstawała w zasadzie przez ostatnie pięćdziesiąt lat. Około ćwierć wieku Profesor Niekludow zajmował się eposem mongolskim, stanowiącym podstawę Jego obydwu dysertacji. Ponieważ zawsze interesował Go zwłaszcza epos o Królu Gesarze, 
czeka właśnie na publikację monografia poświęcona ustnym i literackim wersjom tej epopei. Trzecim wielkim tematem towarzyszącym Jubilatowi od początku kariery naukowej jest mitologia mongolska.

Od roku 1992 Jubilat zaczął zajmować się pieśnią miejską, zwłaszcza analizą porównawczą różnych wariantów danego tekstu, do czego zainspirowała go publikacja pionierskich na tamte czasy wykładów Aleksandra Biełousowa na temat folkloru miejskiego oraz praca o pieśniowym folklorze Gułagu Michel'a i Lidii Jakobsonów. Jeszcze jedną naukową inspiracją dla Profesora Niekludowa była monografia Władimira Cziczerowa o szkołach wykonawców bylin Zaonieża. Zastosowaną w niej metodę porównywania wariantów bylin Badacz zastosował potem w badaniach nad procesem folkloryzacji tekstów literackich i funkcjonowania ich wariantów w tradycji ustnej.

Kolejnym projektem naukowym Profesora jest badanie procesu literackiego metodami folklorystyki, tj. pod kątem funkcjonowania w nim na przestrzeni wieków pewnych modeli narracyjnych. Dzięki wykryciu wspólnych elementów w zabytkach piśmiennictwa pochodzących $\mathrm{z}$ różnych okresów, należących przy tym do różnych tradycji etnicznych i kulturowych można nie tylko zrekonstruować kolejne stadia ich funkcjonowania w kulturze, ale i lepiej zrozumieć procesy tekstotwórcze, które, jak się wydaje, w twórczości ustnej i literackiej przebiegaja bardzo podobnie. Wymaga to oczywiście od badacza ogromnej erudycji, cierpliwości, doświadczenia, tytanicznego wprost wysiłku, ale efekt może przejść najśmielsze oczekiwania. Tak było w przypadku monografii o kozackim atamanie, Stiepanie Razinie (Легенда о Разине: персидская княжна и другие сюжеть, (w druku). Badanie genezy i funkcjonowania wątku razinowskiego w rosyjskiej tradycji literackiej ujawniło ogrom tekstów, który zaskoczył samego Badacza. Jednak najbardziej frapujące w całej pracy okazało się wyjaśnienie jednego $\mathrm{z}$ centralnych epizodów całej raziniany, a mianowicie interpretowanego na wiele sposobów niezrozumiałego postępku Razina, wrzucającego do Wołgi swą ukochaną, perską księżniczkę.

Profesor Niekludow ma jeszcze wiele planów naukowych, co świadczy o wielkiej żywości Jego umysłu. Jeden z nich dotyczy mechanizmów przekształcenia w ,tekst kultury" pierwotnych odczuć wywołanych przez konkretne zdarzenie, które następnie stają się przedmiotem opowieści o charakterze podaniowym, historycznym, balladowym itp. Drugi problem badawczy wiąże się z technologią tekstualizacji, zachowania i przekazywania ,pamięci kulturowej”.

Zamykając jedne, otwierając zaś dla siebie kolejne obszary badań naukowych, Jubilat nie zapomina o kształceniu młodszego pokolenia badaczy, organizując rokrocznie w Peresławiu Zaleskim Szkoły Letnie Folklorystyki i Antropologii Kulturowej. Formuła tego typu spotkań jest bardzo szeroka i obejmuje wykłady prowadzone przez specjalistów, prezentacje materiałów terenowych, pokazy filmów etnograficznych, warsztaty.

Niesłychana erudycja, rzetelność naukowa, obrazowość myśli, ogromna pracowitość, umiejętność widzenia badanych zjawisk w szerokim kontekście kulturowym stanowią o nieprzeciętnym uroku i charyzmie Profesora Siergieja Niekludowa, zwłaszcza że w kontaktach osobistych to człowiek niezwykle ciepły i ujmujący.

\section{IWONA RZEPNIKOWSKA}

\section{THE CELEBRATION OF PROFESSOR SERGEI NIEKLUDOW'S 75TH BIRTHDAY}

\section{SUMMARY}

Professor Sergei Niekludow, the internationally renowned Russian folklorist and the founder and long-time director of the Center for Typological and Semiotic Folklore Studies at the Russian State University for Humanitiesin Moscow, celebrated his 75 birthday on 31st 
March.Professor Niekludowisalso a member of the editorial board and a former senior editor of the prestigious journal Живаястарина.

Sergei Niekludowwas a student of EleazarMeletinskii, an outstanding myth specialist and a folklore and literary scholar. Under his supervision, Niekludow wrote his MA thesis, which he defended in 1965.He received his doctoral degree in 1973 and habilitation—in 1985.

Professor Sergei Niekludowparticipated in international conferences in numerous European countries and in Brazil, China and Mongolia. His research interests are very broad and focus on the theory of folklore, contemporary forms of folklore, the mythology and epics of Mongolian nations, processes of folklorization of literary texts and their existence in oral traditions, as well as on mechanisms of transforming emotions caused by specific events into "texts of culture." The list of professor Niekludow's publications currently includes 589 items of various kinds.

Professor Niekludowhas a lot of further academic plans, which testifies to his great mental vigor.His unique erudition, research integrity, capability for vivid thought, incredible diligence, and ability to see the phenomenon under examination in a broad cultural context, have made Niekludow a role model for generations of folklorists, to whose education he actively contributes.

Translated by Justyna Deszcz-Tryhubczak 